\title{
Ways to integrate Jewish Literature into the Broader Context of Academic Teaching
}

The endeavour to integrate Jewish Literature in current curricula brought to mind a famous and successful writer whose factual life and literary works embody and exemplify many of the issues related to the subject at hand. I am referring to Shatan Bogat, aka Fosco Sinebaldi, aka Émile Ajar. Born in 1914 in Vilna to Russian parents who separated in his childhood, Roman Kassev, as he was called at birth, arrived in Nice at the age of 14, driven there by his fervently Francophile mother, who was convinced France was the only place that could promote her son's obvious talents. A somewhat nightmarishly archetypal Jewish mother, Mina Kassev destined her son to become a "Victor Hugo," a “D’Annunzio," a hero and a French ambassador. Happy to comply, Roman would seek a suitable pen name for his literary career, and ultimately change his name to Romain and then to Romain Gary, the most famous of his many pseudonyms. He would become a French consul to several countries, having been awarded the prestigious medal of the Compagnons de la Liberation by the hands of Charles de Gaulle himself for his bravery in battle as an RAF navigator in WWII, fighting as part of the free French, in the "Lorraine" squadron.

During the war, he would also start his formal career as a writer. In fact, he would become the only French writer to win the most lucrative Goncourt prize not once, as the prize regulations stipulate, but twice: as Romain Gary, for his novel Les raciness du ciel, published in 1956, and for the novel La vie devant soi, published in 1975, under the name of Émile Ajar. It is only after his suicide, on the $2^{\text {nd }}$ of December 1980, that his literary confession was published, officially revealing the connection between Gary and Ajar, to the stupefaction of the great majority of his readers.

Despite his many achievements, Gary was a kind of underdog. A foreigner and a Jew to boot, he was hailed but also classified immediately upon the publication of his first novel, L' education Européenne, written during the war and first published in English in 1944. The novel depicts the struggle for survival of a Jewish child in WWII, amidst Polish partisans fighting the Nazis in the woods around Gary's native town. Gary's otherness was thus established. This distinction, purposefully underlined by Gary's ambiguous attitude towards his own Jewishness, constituted one more building block of his constructed self. On the one hand, he claimed (though this was not corroborated factually) that the Israeli listing of Who's Who in World Jewry refused him an entry since he

Ә OpenAccess. () 2020 Nourit Melcer-Padon, published by De Gruyter. (cc))BY-NC-ND This work is licensed under the Creative Commons Attribution-NonCommercial-NoDerivatives 4.0 License. 
was not really considered a Jew, yet on the other hand he himself insisted that he was of Mongol origin on his father's side $^{1}$ (Gary 2007, 15 -6). His commercial success certainly did not ingratiate him with the French intellectual aristocracy that snubbed Gary, disregarding his literary valour as well as his impeccable use and inventive misuse - of the French language, especially in the novels signed Émile Ajar.

Gary's urge to reinvent his literary self was mainly driven by his conviction that he would never be allowed to step outside the category of the eternal foreigner whose narratives, however various, tiresomely centred on WWII and its repercussions, and on many protagonists who were Jews. For the French, Gary lamented, he would always be an "outsider writer"” (Gary 2007, 37). In order to peel off the label he felt was glued to the name 'Romain Gary' he started writing under a new name: Émile Ajar. Not only did he manage to produce a new style, and seemingly dealt with new themes and social issues in his writing, but he did it so well that only the few in the know could fathom that Gary was the original author. The first Ajar novel, Gros Calin (1974) was quite a success, so much so that it was nominated for the Renaudot Prize, a list from which Gary felt duty-bound to withdraw the novel from, since this was not really his first novel. The second Ajar novel La vie devant soi (1975), became an even greater success, leading to the unforgettable performance of Simone Signoret as Madame Rosa in Moshé Mizrahi’s 1977 film adaptation. Hence, Gary had been quite right in his argument that the name 'Romain Gary' on the cover of a novel could only elicit the same worn-out reaction from critics and public, while 'Émile Ajar' would receive a completely different welcome.

What Gary did not foresee was the extensive effect of this fresh literary triumph. He found himself compelled to concoct a false figure, complete with biographical details that were supposed to keep his real identity hidden. When the readers' pressure to find out who exactly the successful young new writer was grew, Gary convinced his cousin Paul Pavlowitch to pose as Émile Ajar and give interviews that Gary hoped would convince the public and distance the press from the real writer. Matters became complicated: the novel was nominated for the Goncourt prize, and several assiduous reporters found incongruities in

1 In an interview, Gary claimed he had been refused an entry since his father was not Jewish. Supposedly, his $20 \$$ fee was returned, and a letter from the biographical dictionary staff stated the Israeli law supported the decision of Who's Who. This in itself is a fantasy (if not a deception) on Gary's part, since the state of Israel considers anyone whose mother is Jewish as automatically eligible for citizenship, regardless of the father's creed (Gary, 2007, 15-6).

2 Gary compared his literary reception and consideration in France to that of Joseph Conrad in England. (Gary 2007, 37). 
the fabricated story that led to a series of near-discoveries. To dissuade further inquiry, Gary denied he had anything to do with Ajar in a written statement published on Le Monde. Yet what finally convinced the public that Émile Ajar was Paul Pavlowich's pen-name was nothing other than what Gary was masterful at: writing fiction. In a manner reminiscent of E. A. Poe's "Purloined Letter," Gary brilliantly exposed the truth in such a way that it became thoroughly buried under a multi-layered masquerade, composed of truthful statements and real facts. The novel Pseudo (1976), whose very title attests to its content, was construed as a lunatic's journal, supposedly Paul's autobiography, in which he admitted to being treated for schizophrenia in a clinic in Denmark. Many details taken from the long trail of lies accumulated since Émile Ajar came into existence were woven into the novel in a farcical, playfully absurd manner, and convinced the public that Paul Pavlowich was indeed the somewhat troubled but brilliant Émile Ajar. Gary thus admitted to the sham while at the same time tragically renouncing the possibility of publically enjoying the fruits of his labour, and particularly the recognition that his writing skill encompassed much wider possibilities than credited. Nonetheless, he did not give up on the opportunity to saturate Pseudo with the fundamental social, ethical and psychological precepts that can easily be traced in all his novels, regardless of the pseudonym used for each.

Gary's condition, albeit rather extreme, is typical of that of innumerable Jews over many centuries. One recalls the Conversos in Early Modern times, who had to negotiate different rulers, juggle between several identities and somehow reinvent themselves in a new location under precarious conditions, or Jews who later on considered themselves emancipated under the aegis of the age of Enlightenment, only to become disillusioned by the Dreyfus affair. Jews were often forced to adjust at best, or at worst flee for their lives, making their 'relocation' a vital necessity. Nevertheless, the ability to adapt to new circumstances and the versatility that allowed to survive changes while retaining a core identity, are capacities that are also required from displaced people and immigrants in other societies. Common to Italians in early years of the twentieth century in America, to present-day African immigrants' unwelcome arrival on European coasts, indeed to any other minority at any given historical time, are many of the 'Jewish' anxieties resulting from dangers and hardships they must tackle when seeking a safe haven. Gary was very much aware of the universality emphasized by the Jewish condition in his writing. Quoting Arthur Koestler, he claimed Jews were an extreme case of Man, adding that his entire oeuvre was geared at a search of the fundamentally, essentially human (Gary 2007, 25). He viewed his incapacity to lose hope and determination to vindicate Man, as the 
defenceless creature put on earth to try to survive life's challenges as best he can, as the very reason for his creative endeavour.

Gary's flamboyant personality and multi-layered, concealed identities are not the only attributes that made me think of him in the context of the present volume. Rather, it is one of his most powerful novels. Its plot and its date of publication make it doubly interesting, since it was not only written ahead of its time but especially because it was published at the wrong timing. La dance de Genghis Cohn was vehemently opposed by French Jews, who condemned Gary of making fun of the Shoa during the tense days preceding the Seven Days' war between Israel and its neighbouring Arab countries. The book was published three days before the war broke out, and although it was later translated into English by Gary himself, it never received (to my mind at least) proper recognition.

The novel stages the revenge administered by the ghost of a minor Yiddish cabaret comedian, who continues to use his wry Jewish humour to haunt Schatz, the Nazi responsible for his death. It is almost 22 years that Schatz has been hiding a Jew, jokes Cohn, and he can no more rid himself of this ghost than Germany can rid itself of its past. An agent of poetic justice, Cohn proves that Jews are an integral part not only of German history and culture, but also more fundamentally of the German psyche. Similarly to his namesake, Genghis Khan, whose hordes invaded Europe, Cohn freely overtakes the German subconscious, and has no intention of leaving: "they have stuck me in their subconscious, I'm staying there. I cannot be uprooted." 3

While readers laugh at Schatz' dismay when he finds himself suddenly made to talk in Yiddish or to eat chopped liver, other facets of Gary's literary revenge may be less easy to digest. Schatz receives a psychiatric drug, which nearly rids him of the spirit haunting him. Surprisingly, Schatz fights back, and when the effect of the drug wears off, he is not only happy to still be hosting Cohn, but thanks Cohn for having saved him. Flabbergasted, Cohn realizes that victim and culprit are bound forever. Cohn may be inhabiting Schatz' subconscious, but Schatz also inhabits Cohn's subconscious, to the point that Cohn does not know anymore who haunts whom. What's more, they both find themselves knee-deep in a quagmire, a greater subconscious, one that evidently tries to rid itself of both of them. Cohn reflects, and concludes it could be the subconscious of the Messiah, who has come to liberate humans of their individual subconscious and lead them to the light, or it could be God's subconscious, who is trying to relieve himself of humans in order to have some peace and quiet. Clear-

3 “Ils m’ont foutu dans leur sub-conscient, j’y reste. Indéracinable.” (Gary 1967, 34). 
ly, the stinking swamp they are both in belongs not only to the writer, who has inserted them there, but also to a sort of collective subconscious.

Cohn realizes to his horror the ramifications of being considered equal to Schatz: once Jews become part of normative society rather than remaining on its margins, they will also be morally implicated in the collective responsibility for the crimes perpetrated by humans, including their own extermination. Cohn rebels against the very idea that the victim could possibly have anything to do with the crime. He promptly decides fraternity with others is not for him, since the minute he accepts to be part of the human race he would have the blood of the victims of Hiroshima and of the Blacks in America on his hands.

According to Gary, the surviving victim must acknowledge Nazi conduct as part of the possible scope of human depravity, rather than the deeds of insane or inhuman people. The reintegration of the Jew into his rightful place within the rank of the human race compels one at the same time to take a renewed look at the Nazis, the French and all the other people who lived through the horrific times of WWII. The responsibility for the actions carried out by nations is laid not only at the door of their leaders, but also on the private thresholds of each individual citizen. "Pinochet and Amin Dada, are you and me," claims the main protagonist of Gary's novel Pseudo. As Gary said in an interview, he considered the entire Humanity to be the "I" of Genghis Cohn, its main protagonist and its main subject (Gary 2007, 34). The only way to avoid responsibility is by not being human at all, and the protagonist yells: "Fuck off! I don't know what I've done next, I don't read newspapers, but it wasn't me. I'm not the sort to. I am a disgusting reptile. I am nothing human. I am not responsible."4 (Gary 2010, 11, 16).

Inspired by Gary, we can move forward and think of ways to combine organically into a working program his vision, his iconoclastic and irreverent stances, taken from Jewish traditions, which are undoubtedly relevant to Israeli literature, though mostly still unknown to European students. Gary's use of Yiddish humour, of jokes about the Shoa, of absurdity and dystopia, does not stand

4 In French: Ajar 1976, 20, 25: “ Pinochet et Amin Dada, c'est vous et moi ... Foutez-moi la paix. Je ne sais pas ce que j'ai encore fait, je ne lis pas les journeaux, mais c'est pas moi. C'est pas mon genre. Je suis un reptile répugnant. Je n'ai rien d'humain. Je suis pas responsible.” Gros Calin, Gary's first novel as Émile Ajar, is about a man who keeps a python as his pet, and ultimately becomes the python, rolling his coils and eating mice, having relinquished his frenetic pursuit of human affection. In Kites, the French cook and the German general cook together: "Nous sommes tous dans le sang et dans la merde et deux natures d'élite communient au-dessus de la barbarie ... Ces deux-là sont en train de préparer l'avenir. Bordel, j’aimerais voir ça.” (Gary 1980, 285). 
alone but indeed fits quite naturally in a continuum very much alive today as well. From Itzik Manger and Y. L. Peretz' Yiddish humour, to Orly Castel-Bloom's, Amos Kenan's and Benjamin Tamuz' dystopian novels, to Hanoch Levin's satirical Shoa plays, the legacy of Jewish history and literature that impregnated Gary's writing is kept alive in present day Israeli fiction. Such a combination of texts can also serve as an example to my modest suggestion of how to integrate Jewish literature and specifically modern Israeli fiction into European academic studies.

There are several problematic aspects when envisaging the integration of Jewish Literature in broader academic teaching. First, what is "Jewish Literature"? ${ }^{5}$ How can it be defined - and should there be a conclusive definition? Would such a category include only literature written in Hebrew and in languages of the Jews, and/or literature written by Jews (and we can't fail to observe that there is no agreed upon answer to the age-old question "Who is a Jew?")? Should there be a differentiation between literature written in the land of Israel (from Biblical times to post-1948) and in the diaspora? Would there be a reference to the period in which this literature was written? In addition, can one consider certain texts as canonical texts, and if so what is the criteria for this category? Finally, the language in which Jewish texts were written, and the language into which they were translated play a major part of the possibility to include them in any program. For example, a text written in Yiddish and only translated into Hebrew, or a text that was translated from Hebrew but only into English, could be problematic for target readers in French or Italian universities.

I suggest producing modular study units, and the texts I have just mentioned with relation to Gary and his style could become one such module about the use of humour in literature. These modules could be taught separately or one after the other, depending on the needs of the target university. Integrating the study of Jewish texts into existing programs could rely on the professors presently teaching them and would therefore not necessitate the establishment of a special department or a chair for Jewish studies. Each module would be conceived in a manner that provides the suggested titles and an accompanying bibliography, as well as several relevant critical texts.

The full sequence of the modules could create an historical continuum, a time line along which the various texts would be discussed, according to their time of writing and/or publication. Such an approach would also provide the historical and social context in which each work was conceived and would constitute a full-length course on the subject of Jewish literature. Alternatively, each

5 For a discussion of this issue, see: Salah 2003, 95-120. 
of the modules could be studied separately, and fit into an existing curriculum, according to period and/or to geographical location studied at the target university. ${ }^{6}$ Another option would be for teachers of Jewish literature to provide online courses that would be added to current course requirements. One such course presently exists in France, at the Lorraine University.

A clear constraint to this suggestion is the fact that any lists of existing Jewish works that have already been translated would necessarily contain diverse texts for various target countries. There are great differences between texts chosen to be translated into German, French or Italian, and translations into English would provide a different list altogether. Moreover, even a cursory examination of trends in publishing of translations of Hebrew literature reflects the underlying political reality: the tendency to publish such translations is very much in correlation with the current political atmosphere created in Europe and elsewhere at any given time. For example, the 1967 War or the signing of the Oslo Agreements (1992): both occurrences resulted in a positive political attitude towards Israel at the time, and produced a significant increase in the publication of literary translations from Hebrew in Europe and the United States. ${ }^{7}$ Authors of the Israeli left, such Amos Oz or David Grossman, are more often than not invit-

\section{Examples for possible units:}

A. a unit based on Gary's texts could be divided into three parts: 1. 'Beginnings': La Promesse de l'aube as well as Yoel Hofmann's curriculum vitae [no capital letters in the original] and Amos Oz's A Tale of Love and Darkness; 2. 'Birth of the Author': Pour Sganarelle, and Pseudo, as well as Hélène Cixous' “Coming to Writing”; 3. 'The Multiple 'I': reading Gary's texts against the background of Luigi Pirandello's Six Characters in Search of an Author and One, a Million and No One and Fernando Pessoa's The Book of Disquiet.

B. a comparative approach: in a French course that centers on Marcel Proust's Du Côté de chez Swann, one could add a discussion of S. Yizhar's The Days of Ziklag [Yemey Ziklag]; in a course that includes Georges Perec's W ou le Souvenir d'enfance, one could read Yoel Hofmann's Katschen and The Book of Joseph; in a course that discusses Claude Simon's La Route des Flandres, one could add Yizhak Averbuch's The Young Man [Haelem].

In an Italian course focusing the subject of "War and its aftermath," that would include texts such as Umberto Eco's La fiamma della regina Loanna, one could consider adding a discussion of Israeli texts such as Yehudit Hendel's The Mountain of Losses or David Grossman's To the End of the Land.

C. a themed approach comprising only of Jewish literature:

aside for the abovementioned course on "Humour", one could present a course entitled "The Auto portrait”, that would include the following texts: H. N. Bialik's Safiakh; Tchernichovsky's autobiographical idylls, S.Y. Agnon's “Agunot”; Lea Goldberg's And this is the Light [Vehu Haor]; Yoel Hofmann's The Book of Josheph; Dan Tsalka's Portrait of the Artist at the Age of 27; Anton Shammas' Arabesques. In addition, one could envisage adding texts that would probably be known to the students: Amos Oz's Black Box, and A. B. Yehoshua's Mr. Mani.

7 For the political influence on literary reception in Italy and France, see: Carandina 2014. 
ed to voice their political views at interviews and lectures and op-ed pieces, rather than contribute their literary input. To the politics of translation, one must add the local politics of editors and distributors in Europe and the US. In such a reality, the integration of Hebrew/Jewish literature in the future, from a cultural and academic point of view, should not be held hostage to the mood of the moment.

Indeed, an important way to promote the reading, propagation and eventual integration of Jewish literature in academic studies, lies in further promotion of translation. ${ }^{8}$ Many Israeli authors are compelled to translate their work at their private expense, an effort that is not necessarily rewarded with publishing, similarly to the Israeli government's effort to sponsor translations by setting up a special fund, which often resulted in disappointment. In an ideal world, one could fathom the appointment of lectors who could compile lists of relevant texts and engage translators into various target languages. Until such time arrives, one could envisage using existing English translations, especially since these often appear before translations into other languages. ${ }^{9}$ The National Library of Israel could assist the project by producing a list of all books that have been translated to date, according to language into which the books were translated and the time of translation, with added information regarding publishers, translators and more, all readily available in its databases.

It would be advisable to take Jewish literature out of its expected, "comfort zone," or habitual niche it has been classified under. In other words, while offering modules on Shoa literature, or famous and commercially well-known modern authors such as David Shahar in France or A.B. Yehoshua in Italy, not to be merely guided or restricted to these denominators, but rather to embrace a broader outlook and comparative approach. Such an approach would wrest the subject from the hands of commercial interests, alien to academic work and offer a no-nonsense, clear-eyed look at the material we wish to integrate, thus enabling us to expose its riches and possibilities. Jewish texts present a plethora of thematic foci, of stylistic features, of writing styles and of artistic approaches, especially since they are part of a living classical culture, with a continuous existence of over 3000 years.

8 The site of the Institute for Translation of Hebrew Literature provides a comprehensive list of translated Hebrew books that have been translated into 82 languages. See: http://www.ithl.org.il/. (14 June 2019).

Specifically for translations of Jewish texts into Italian, see: https://www.israele.net/letteratura-ebraica-contemporanea-pubblicata-in-italiano. (14 June 2019).

9 Regarding translations into French that customarily appear after English ones, see: Sapiro 2002, 84. 
Writers like Romain Gary, whose tools, apparent in all his works, are humour, absurdity, slapstick, ridicule, and breaking of taboos, all used to put an uncomfortable mirror in front of society, thereby undermining exceptionalism - should be considered as beacons to such a project. Particularly if one is willing to adopt Gary's reflection regarding Jews, a mere twenty-five years after Auschwitz: while admitting to the short time that had passed, he considered that the extreme situations Man now had to face no longer belonged to the Jews, in terms of suffering (Gary 2007, 26). Far from forgetting Auschwitz or minimizing its unprecedented horror, Gary believed it was time to consider other sufferings as well, since even Auschwitz did not put a stop to man's capacity to inflict them upon other fellow men.

\section{Bibliography}

Ajar, Émile. Pseudo. Paris: Mercure de France, 1976.

Carandina, Elisa. "Per un canone esterno della nuova letteratura ebraica." Griselda online 2014. https://site.unibo.it/griseldaonline/it/letterature-del-mondo/elisa-carandina-can one-esterno-nuova-letteratura-ebraica (24 September 2019).

Gary, Romain. Hocus Bogus. Trans. David Bellos. Pennsylvania: Margellos World Republic of Letters, 2010.

Gary, Romain. Le judaïsme n'est pas une question de sang. Paris : L'Herne, 2007.

Gary, Romain. Les cerfs volants. Paris: Gallimard, 1980.

Gary, Romain. Genghis Cohn. Paris: Gallimard, 1967.

Salah, Asher N. "Y a-t-il eu un roman hébraïque? Roman et romanesque dans la littérature juive en Europe occidentale du XVI ${ }^{\mathrm{e}}$ au $\mathrm{XVIII}{ }^{\mathrm{e}}$ siècle." Rhétoriques méditerranéennes 7 (2003): 95-120.

Sapiro, Gisele. "L'importation de la Litterature Hebraique en France: entre Communautarisme et Universalisme.” Actes de la recherche en science sociales 144.4 (Septembre 2002): $80-98$. 
